\title{
Aktivitas Argumentasi dalam Kegiatan Eksperimen Fisika: Analisis Respon Mahasiswa
}

\author{
S. Yulianci ${ }^{*}$, S. Siswanto ${ }^{2}$, Yusiran ${ }^{3}$, Hartono $^{4}$, B. Subali ${ }^{4}$ \\ ${ }^{1}$ Program Studi Pendidikan Guru Sekolah Dasar, STKIP Taman Siswa Bima, Bima, Indonesia \\ ${ }^{2}$ Program Studi Pendidikan Ilmu Pengetahuan Alam, Universitas Tidar, Magelang, Indonesia \\ ${ }^{3}$ Program Studi Pendidikan Fisika, STKIP Taman Siswa Bima, Bima, Indonesia \\ ${ }^{4}$ Program Studi Pendidikan Fisika, Universitas Negeri Semarang, Semarang, Indonesia \\ *Coresponding author: yulianci_syah@gmail.com
}

\section{ART I CLE INFO}

Article history:

Received: Mei 2019

Accepted: September 2019

\section{Keywords:}

Argumentasi ilmiah, eksperimen fisika, model eksperimen

\begin{abstract}
ABSTRAK
Kegiatan eksperimen merupakan salah satu faktor penting dalam mencapai tujuan pembelajaran fisika. Penelitian ini bertujuan untuk memperoleh gambaran mengenai respon mahasiswa terhadap aktivitas argumentasi yang disisipkan dalam kegiatan eksperimen fisika. Kegiatan eksperimen yang disisipi aktivitas argumentasi yaitu tahapan aktivitas laboratorium inkuiri, yang meliputi tahap (1) mengidentifikasi masalah, (2) merumuskan tujuan, (3) merumuskan hipotesis, (4) merancang prosedur eksperimen, (5) melakukan kegiatan eksperimen, (6) melakukan interpretasi data, (7) menyimpulkan. Sedangkan aktivitas argumentasi yang disisipkan meliputi aktivitas mengajukan klaim, data, pembenaran, dan dukungan. Penelitian ini dilakukan dengan melibatkan 100 mahasiswa di tiga perguruan tinggi yang berbeda. Data diperoleh melalui angket respon mahasiswa dan wawancara terbuka. Analisis data dilakukan secara kualitatif dan kuantitatif. Secara umum, kegiatan eksperimen mendapatkan respon yang positif dari mahasiswa.
\end{abstract}

\section{PENDAHULUAN}

Kegiatan eksperimen dalam proses pembelajaran sains, dalam hal ini fisika, sangatlah penting. Pelaksanaan kegiatan eksperimen menjadi salah satu faktor yang dapat mempengaruhi keberhasilan capaian hasil belajar fisika. Menurut Gilbert \& Reiner (2010), dalam proses pembelajaran fisika perlu untuk membiasakan kegiatan-kegiatan eksperimen. Pentingnya kegiatan eksperimen dikarenakan mampu memudahkan mahasiswa dalam menyerap, mengelaborasi, dan membangun konsep (Ali, \& Arif, 2019; Stern, 2017).

Saat ini, tren kegiatan eksperimen mulai mengalami pergeseran dari traditional laboratory activity kepada modern laboratory activity (Bahtiar dan Dukomalamo, 2019). 
Aktivitas dalam bereksperimen saat ini sudah tidak lagi menggunakan cook book eksperiment (ciri khas traditional laboratory activity) yang seluruh kegiatannya diatur oleh modul eksperimen (seperti kumpulan resep masakan). Akan tetapi, kegiatan eksperimen saat ini lebih terarah pada kegiatan yang digali dan dieksplorasi sendiri oleh mahasiswa (ciri khas modern laboratory activity).

Kegiatan "cook book experiment" memiliki beberapa kelemahan. Beberapa temuan menunjukkan bahwa "cook book experiment" membuat proses pembelajaran menjadi tidak bermakna, beberapa hasil belajar menjadi kurang maksimal untuk ditingkatkan baik untuk aspek keterampilan maupun kemampuan kognitifnya, dan menimbulkan kebosanan bagi para mahasiswa (Domin, 1999; Krasilchik, 2007; Gilbert\& Reiner, 2010; Stern, 2017).

Berbeda dengan Kegiatan "cook book experiment", aktivitas eksperimen yang ada dalam modern laboratory activity, jika dirancang dengan baik mampu membuat proses pembelajaran menjadi lebih bermakna. Hasil penelitian Stern (2017) dan Sampson (2010) menunjukkan bahwa kegiatan eksperimen dalam proses pembelajaran yang dilakukan dengan menekankan pada keaktifan mahasiswa mampu membuat proses pembelajaran menjadi lebih menyenangkan. Karakteristik "modern laboratory activity" yaitu menekankan pada kegiatan-kegiatan yang membiasakan mahasiswa untuk bertindak dan berpikir seperti seorang ilmuwan.

Pada penelitian ini, peneliti melakukan inovasi dengan menyisipkan aktivitas argumentasi dalam "modern laboratory activity". Aktivitas argumentasi yang disisipkan dalam kegiatan eksperimen diharapkan mampu membuat proses pembelajaran menjadi lebih menyenangkan dan memotivasi. Beberapa hasil penelitian menunjukkan temuan bahwa proses pembelajaran yang di dalamnya melatihkan kegiatan berargumentasi dapat lebih memudahkan dalam menguasai konsep (Zohar, 2002; Mc. Neil, 2006; Sampson, 2010; Siswanto, 2014; Yusiran, 2016). Harapannya, jika konsep mudah untuk dipahami, mahasiswa menjadi lebih senang dan termotivasi untuk mengikuti proses pembelajaran (Fauzi \& Fariantika, 2018; Rosamsi, Miarsyah, \& Ristanto, 2019).

Oleh sebab itu, penelitian ini dilakukan dengan tujuan untuk mendapatkan gambaran mengenai respon mahasiswa terkait dengan aktivitas argumentasi yang disisipkan dalam kegiatan eksperimen fisika melalui aktivitas laboratorium moderen

\section{METODE}

Penelitian ini dilakukan dengan melibatkan 100 mahasiswa di tiga Perguruan Tinggi. Gambaran desain penelitian dapat dilihat pada Gambar 1.

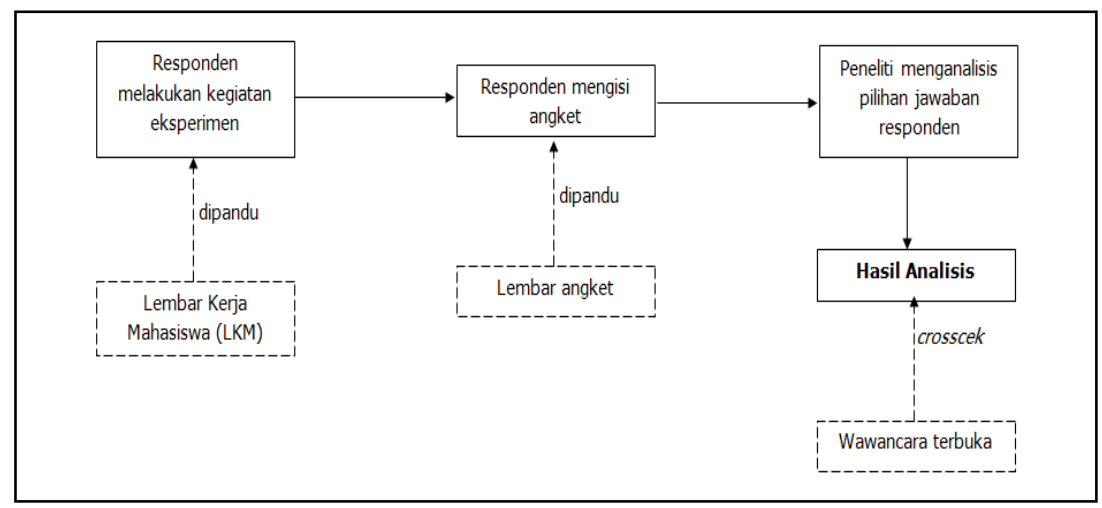

Gambar 1. Desain Tahapan Penelitian yang Dilakukan

Instrumen yang digunakan pada penelitian ini yaitu (1) angket, digunakan untuk mendapatkan gambaran terkait dengan respon mahasiswa terhadap aktivitas argumentasi dalam kegiatan eksperimen fisika. Angket yang digunakan berupa daftar pertanyaan dengan pilihan jawaban "ya" dan "tidak" yang disertai dengan alasan memilih jawaban. 
Hasil isian angket mahasiswa kemudian dihitung persentase pilihannya. (2) wawancara terbuka, digunakan untuk mengkroscek data yang terkumpul melalui angket yang diisi oleh mahasiswa. Wawancara dilakukan berdasarkan pada temuan-temuan dalam isian angket. Analisis data dilakukan dengan melakukan analisa mendalam terhadap isian hasil angket yang beberapa temuan dilakukan crosscek melalui wawancara terbuka.

\section{HASIL DAN PEMBAHASAN}

Pada bagian ini, dijelaskan temuan penelitian dan selanjutnya diberikan pembahasan yang komprehensif. Temuan dapat disajikan dalam bentuk gambar, grafik, tabel, dan lain-lain untuk mempermudah pembaca dalam memahami. Pembahasan dapat dibagi menjadi beberapa subbab.

Penelitian ini terbagi dalam tiga tahapan. Pada tahap pertama, mahasiswa melakukan kegiatan eksperimen dalam bentuk "modern laboratory activity" yang disisipi dengan aktivitas argumentasi. Aktivitas laboratorium modern yang dipilih secara umum merupakan tahapan dalam kegiatan berinkuiri yang meliputi (1) tahapan mengidentifikasi masalah, (2) tahapan merumuskan tujuan eksperimen, (3) tahapan merumuskan hipotesis, (4) tahapan merancang prosedur eksperimen, (5) tahapan melakukan kegiatan eksperimen, (6) tahapan melakukan interpretasi data, (7) tahapan menyimpulkan (Wenning, 2011; Harlen, 2014; Stern, 2017). Kemudian, didalam tahapan berinkuiri tersebut disisipkan kegiatan argumentasi.

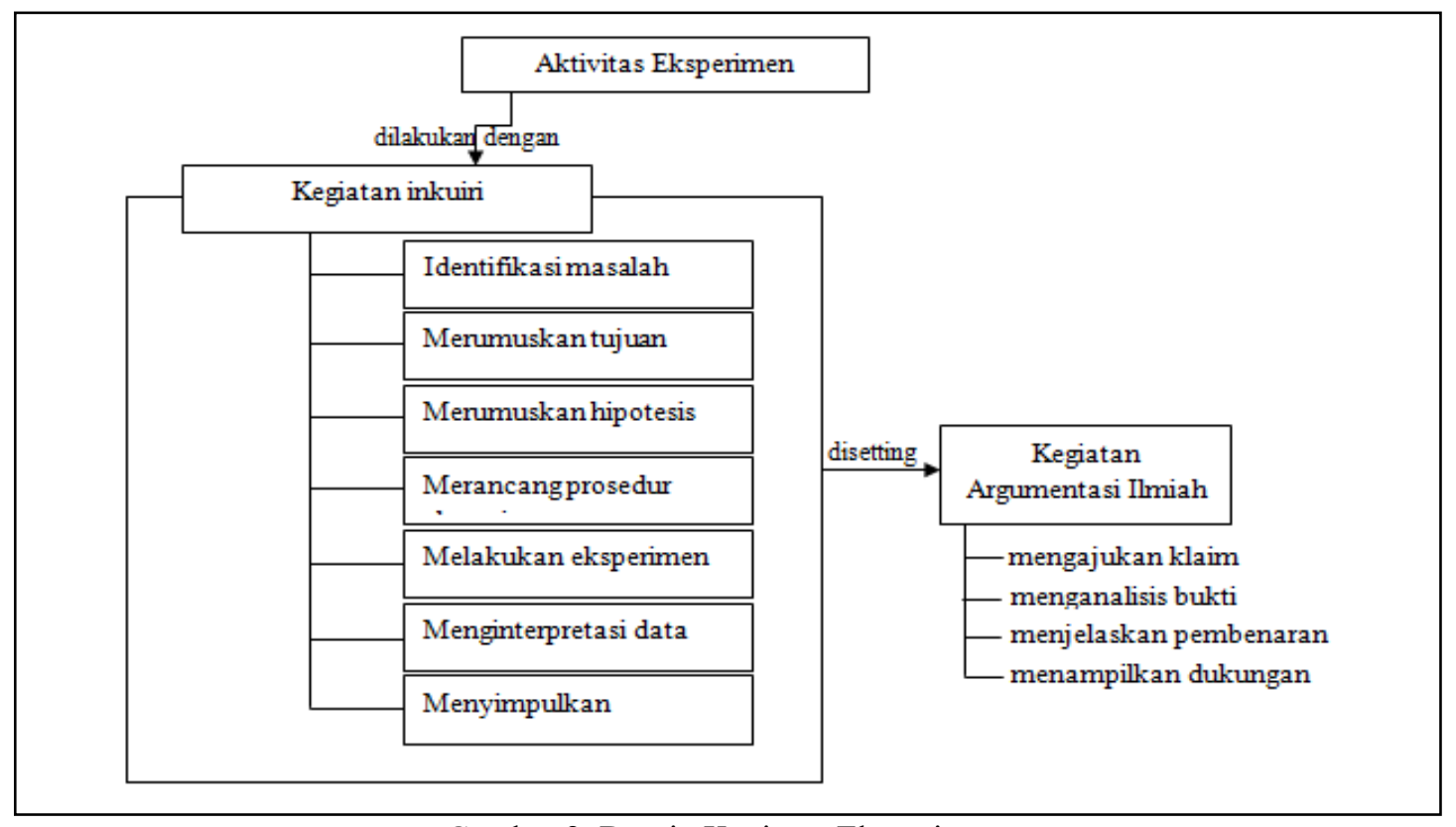

Gambar 2. Desain Kegiatan Eksperimen

Aktivitas argumentasi yang dilakukan merujuk pada Toulmin Argumentation Pattern (Toulmin, 2003), yang meliputi 4 unsur yaitu: (1) Klaim (claim), merupakan kalimat yang diajukan kepada orang lain untuk diterima sebagai kebenaran; (2) Bukti (Data), merupakan kebenaran yang mendasari suatu klaim yang berupa penalaran sehingga klaim sudah tidak dapat dipertentangkan lagi; (3) Pembenaran (Warrant), berupa kalimat yang menjelaskan hubungan antara klaim dengan bukti yang diajukan; (4) Dukungan (Backing), merupakan ungkapan tambahan untuk mendukung pembenaran berupa teori atau fakta.

Desain kegiatan eksperimen yang dilakukan dapat dilihat pada Gambar 2. Aktivitas argumentasi, seperti kegiatan mengajukan klaim, bukti, pembenaran, dan dukungan dilakukan untuk mengkonstruk pengetahuan yang didapat mahasiswa melalui kegiatan eksperimen. Seluruh kegiatan ini, dipandu oleh Lembar Kerja Mahasiswa. 


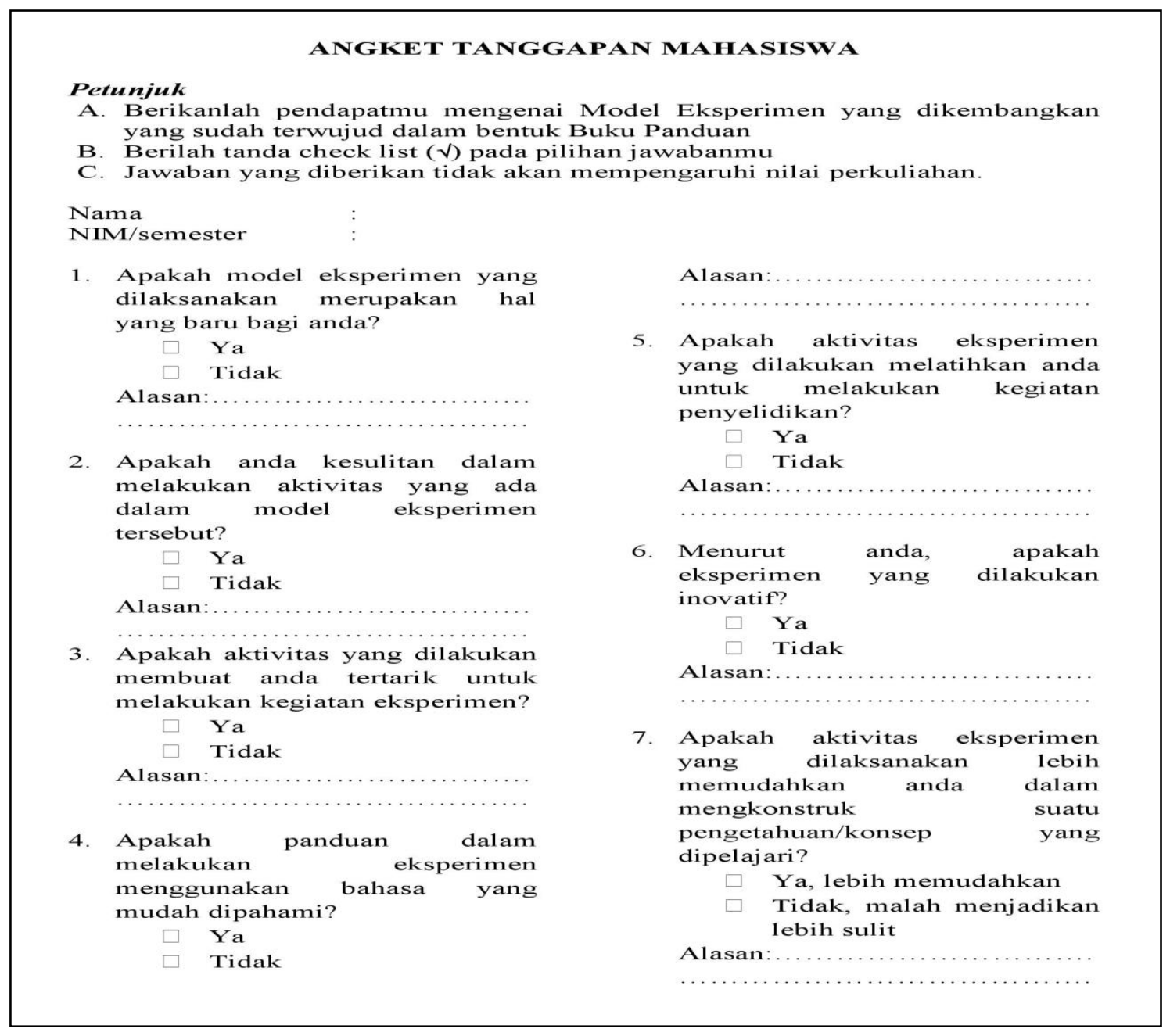

Gambar 3. Angket Respon Mahasiswa

Selanjutnya, pada tahap kedua, mahasiswa mengisi angket. Angket terdiri dari tujuh daftar pertanyaan. Ketujuh daftar pertanyaan tersebut mendeskripsikan tentang respon dari mahasiswa terkait dengan kegiatan eksperimen yang sudah dilakukan oleh mahasiswa. Secara lengkap, bentuk angket yang digunakan dapat dilihat pada Gambar 3 .

Selanjutnya, setelah dilakukan pengisian oleh mahasiswa, tahap terakhir melakukan analisa hasil isian dan kemudian melakukan crosscek melalui wawancara kepada beberapa mahasiswa. Hasil analisa mengenai respon mahasiswa terhadap kegiatan eksperimen disajikan pada Gambar 4. Berdasarkan hasil analisa tersebut, secara umum respon mahasiswa terhadap kegiatan eksperimen yang dilakukan menunjukkan respon yang positif, sehingga kegiatan eksperimen layak untuk diterapkan kepada mahasiswa.

Pada poin pertanyaan nomor 1 , seluruh mahasiswa menyatakan bahwa kegiatan eksperimen yang dilakukan merupakan hal yang baru bagi mereka. Selain itu, juga pada poin pertanyaan nomor 6 , seluruh mahasiswa sepakat bahwa kegiatan eksperimen yang dilakukan memiliki nilai inovasi. Secara keseluruhan, baik untuk pertanyaan nomor 1 dan 6, mahasiswa beralasan bahwa mereka belum pernah melakukan aktivitas-aktivitas eksperimen tersebut. Hal tersebut juga ditegaskan dalam temuan melalui wawancara terbuka. Dipilih 10 mahasiswa untuk menjadi sampel. Mahasiswa mengatakan bahwa mereka belum pernah melakukan kegiatan eksperimen yang di dalamnya terdapat aktivitas argumentasi. 


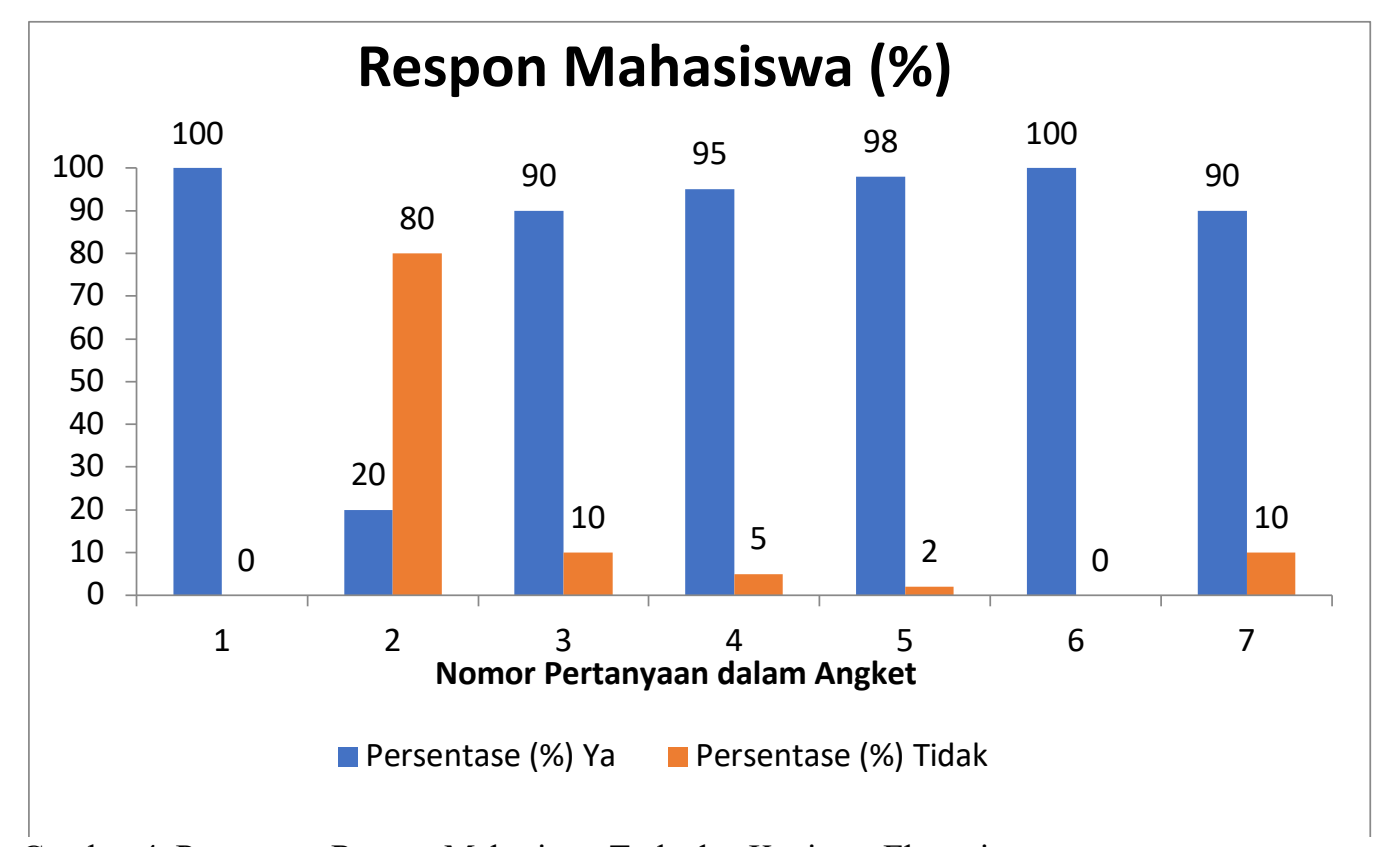

Gambar 4. Persentase Respon Mahasiswa Terhadap Kegiatan Eksperimen

Pada poin pertanyaan nomor 2, 80\% mahasiswa menyatakan bahwa aktivitas eksperimen yang dilakukan tidak sulit. Hanya 20\% mahasiswa yang merasa kesulitan dalam melakukan aktivitas eksperimen. Berdasarkan hasil wawancara, kesulitan mahasiswa dalam melakukan aktivitas eksperimen disebabkan karena merupakan hal yang baru bagi mereka, terutama pada kegiatan merumuskan argumentasi. Selain itu, juga disebabkan karena bahasa yang digunakan dalam panduan melakukan eksperimen mudah untuk dipahami. Berdasarkan temuan, 95\% mahasiswa menyatakan bahwa bahasa yang digunakan dalam kegiatan eksperimen mudah untuk dipahami (temuan angket pada poin pertanyaan nomor 4).

Sedangkan, pada poin pertanyaan nomor 3,90\% mahasiswa menyatakan bahwa inovasi yang dilakukan dalam kegiatan eksperimen membuat mereka tertarik untuk melakukan kegiatan eksperimen tersebut. Berdasarkan temuan dalam kegiatan wawancara, mahasiswa merasa tertarik dalam melakukan aktivitas eksperimen karena tertantang dalam merumuskan argumentasi ilmiah secara utuh. Sementara itu, 10\% mahasiswa yang menyatakan bahwa mereka tidak tertarik lebih banyak disebabkan karena mereka kesulitan dalam melakukan kegiatan eksperimen.

Pada pertanyaan nomor 5, 98\% repsonden menyatakan bahwa aktivitas eksperimen yang dilakukan melatihkan kegiatan penyelidikan. Berdasarkan temuan tersebut, maka aktivitas argumentasi dalam kegiatan eksperimen tidak mengabaikan hakikat sains (fisika) sebagai proses dan produk. Kegiatan-kegiatan ilmiah tetap dapat dibangun dengan menyisipkan aktivitas argumentasi dalam kegiatan eksperimen. Kemudian, 2\% mahasiswa yang menjawab "tidak", berdasarkan kegiatan wawancara, lebih disebabkan karena mahasiswa merasa kesulitan dalam melakukan eksperimen.

Selanjutnya, berdasarkan pertanyaan nomor 7, 90\% mahasiswa menyatakan bahwa kegiatan eksperimen yang dilakukan memudahkan mereka untuk mengkonstruk suatu pengetahuan/konsep. Berdasarkan hasil wawancara, mahasiswa lebih termotivasi untuk melakukan kegiatan eksperimen dengan adanya aktivitas argumentasi, sehingga membuat mereka lebih mudah untuk memahami konsep. Aktivitas-aktivitas argumentasi yang dibangun dalam kegiatan eksperimen, menurut membantu untuk mengkonstruk pengetahuan/konsep secara runtut, utuh, dan jelas (Darmawan, Brasilita, Zubaidah, \& Saptasari, 2018). Sedangkan 10\% mahasiswa yang menganggap bahwa kegiatan eksperimen tidak memudahkan dalam mengkonstruk konsep, disebabkan karena mahasiswa kesulitan dalam membuat argumentasi secara utuh. Aktivitas tersebut 
merupakan hal yang baru, sehingga mereka kesulitan untuk melakukannya.

Berdasarkan analisis tersebut, secara keseluruhan mahasiswa menunjukkan respon yang positif terhadap aktivitas eksperimen. Hal ini sesuai dengan beberapa temuan penelitian yang menunjukkan bahwa ada dampak yang positif terhadap capaian hasil belajar (Siswanto, 2014; Siswanto, 2017; Gumilar, 2018; Gumilar, 2019).

\section{KESIMPULAN}

Berdasarkan temuan penelitian, dapat disimpulkan bahwa kegiatan eksperimen fisika yang menyisipkan aktivitas argumentasi mendapatkan respon yang positif dari mahasiswa, sehingga perlu untuk diterapkan di kelas. Penerapan di kelas dapat dilakukan baik secara langsung melalui mata kuliah praktikum maupun perkuliahan teori yang menggunakan metode praktikum.

\section{DAFTAR PUSTAKA}

Ali, A., \& Arif, W. P. (2019). Developing of guidance for laboratory practice of islamic science-integrated plant anatomy-physiology. Biosfer: Jurnal Pendidikan Biologi, 12(1), 70-82

Bahtiar, B., \& Dukomalamo, N. (2019). Basic science process skills of biology laboratory practice: improving through discovery learning. Biosfer: Jurnal Pendidikan Biologi, 12(1), 83-93.

Darmawan, E., Brasilita, Y., Zubaidah, S., \& Saptasari, M. (2018). Enhancing metacognitive skills of students with different gender using simas eric learning model at state senior high school 6 Malang. Biosfer: Jurnal Pendidikan Biologi, 11(1), 48-57.

Domin, S. (1999). A Review of Laboratory Instruction Styles. Journal of Chemical Education, 76 (4): 543-547.

Fauzi, A., \& Fariantika, A. (2018). Courses perceived difficult by undergraduate students majoring in biology. Biosfer: Jurnal Pendidikan Biologi, 11(2), 78-89.

Gilbert, J.K., \& Reiner, M. (2010). Thought experiments in science education: potential and current realization. International Journal of Science Education, 22(3): 265-283.

Harlen, W. (2014). Helping children's development of inkuiri skills. Inkuiri in primary science education (IPSE), 1: 5-19.

Krasilchik, M. (2007). The scientists: an experiment in science teaching. International Journal of Science Education, 12(3): 282-287.

Mc. Neil, K. L., Lizotte, D. J., \& Karjcik, J. (2006). Supporting Student's Construction of Scientific Explanations by Fading Scaffolds in Instructional Materials. The Journal of The Learning Science, 15 (2), 153-191.

Rosamsi, S., Miarsyah, M., \& Ristanto, R. H. (2019). Interactive multimedia effectiveness in improving cell concept mastery. Journal of Biology Education, $8(1), 56-61$.

Sampson, V., \& Gerbino, F. (2010). Two Instructional Models That Teacher Can Use to Promote \& Support Scientific Argumentation In the Biology Classroom. The American Biology Teacher, 72 (7): 427-431. 
Siswanto, Kaniawati, I. Suhandi, A. (2014). Penerapan Model Pembelajaran Pembangkit Argumen Menggunakan Metode Saintifik untuk Meningkatkan Kemampuan Kognitif dan Keterampilan Berargumentasi Siswa. Jurnal Pendidikan Fisika Indonesia, 10 (2): 104-116.

Siswanto, S., Asriyadin, A., Yusiran, Y., \& Subali, S. (2017). INQUIRY BY DESIGN ARGUMENTATION ACTIVITY: MELATIHKAN KEMAMPUAN KOGNITIF PADA PEMBELAJARAN FISIKA. Gravity: Journal Research and Learning Physics (Gravity: Jurnal Ilmiah Penelitian dan Pembelajaran Fisika), 3(1).

Gumilar, S., \& Subali, B. (2018, March). Scientific method by argumentation design: learning process for maintaining student's retention. In Journal of Physics: Conference Series (Vol. 983, No. 1, p. 012021). IOP Publishing.

Gumilar, S., Ismail, A., Budiman, D. M., \& Siswanto, S. (2019, February). Inquiry instructional model infused blended experiment: helping students enhance critical thinking skills. In Journal of Physics: Conference Series (Vol. 1157, No. 3, p. 032009). IOP Publishing.

Stern, C., Echeverria, C., Porta, D. (2017). Teaching Physics through Experimental Projects. Procedia IUTAM, 20: $189-194$.

Toulmin, S. (2003). The Uses of Argument. New York: Cambridge University Press.

Wenning, C., J. (2011). Experimental inkuiri in introductory physics courses. Journal of Physics Teacher Education, 6 (2): 2-8.

Yusiran, Siswanto. (2016). Implementasi Metode Saintifik Menggunakan Setting Argumentasi untuk Meningkatkan Kemampuan Kognitif. Jurnal Penelitian dan Pengembangan Pendidikan Fisika, 2(2): 15-22.

Zohar, A., \& Nemet, F. (2002). Fostering students knowledge and argumentation skills through dilemmas in human genetics. Journal of research in science teaching, 39 (1), 35-62. 